\title{
The Abolition of National Exams: A Slap for Education System in Indonesia
}

\author{
Lambok Hermanto Sihombing ${ }^{1}$, Fanny Fanani Rachman ${ }^{2}$ \\ ${ }^{1}$ Universitas President \\ ${ }^{2}$ International Relations Universitas President \\ Email: lambok@president.ac.id, fannyfananirachman@gmail.com
}

\begin{abstract}
This research article is analyses the ineffectiveness of National Exams to be conducted specifically for the measurement for graduation that actually did not become the one to be a measurement tools as there are still school final examinations that may become other measurement tools for the student graduation. As there are idea of abolishing the national exams and replace it to other measurement for graduations, the author thoughts that there should be an effort on finding better measurement for graduation. Further, it explores more reason on why the National Exams became ineffective. The author takes this case in order to search for academic perspective in viewing the National Exams ineffectiveness and should be replaced to other measurement tools for high school graduation.
\end{abstract}

Key words: National Exams, Evaluation, Education, High School Graduation

\section{INTRODUCTION}

The Indonesia's National Exams (Ujian Nasional) has been around since a long time ago. The name and the aim were changed periodically, and it was started at 1950 and evolved until 2014. In the beginning of the uses of the National Exam which in 1950, firstly it was named Ujian Penghabisan that around until 1965. The materials for Ujian Penghabisan were made by Departemen Pendidikan, Pengajaran, dan Kebudayan.

Then, it evolved to be Ujian Negara at 1965 until 1971, where the time and the materials were determined by the Central Government and it aimed to determine the graduation system, which the one who passed the exams are able to continue the education to public universities, while the one who were not passed the exams, they still got the graduation certificate, but they should go to private universities.

In the next period, which is 1972 until 1979, it changed its name to be Ujian Sekolah, where the exams held by each school and the Central Government only set the guidelines of the common exams. Then, in 1980 until 2001, the name changed again into
Evaluasi Belajar Tahap Akhir National (EBTANAS) which have two kind of exams.

The first one, EBTA that examine subjects that excluded on EBTANAS where the school coordinated with provincial government. For the second one which is EBTANAS, schools were coordinated with the Central Government, and the aim were controlled, evaluated, and develop the quality of educations. The graduation at that time determined by the score sum of EBTA, EBTANAS, and the daily test record in the report sheet. In 2002 until 2004 the name changed to Ujian Akhir Nasional; it replaces EBTANAS. Then, a new way and system created in 2005 until 2012 named Ujian Nasional that replaced Ujian Akhir Nasional to be the requirement for graduation.

For the last changed, the recent one was in 2014, the Ujian Nasional was done in using Computer System. At this period, Ujian National is not the determining reason for graduation. The graduation was determined by the school, when the students are graduated, they will receive a certificate from the Country. If the student fail, then the one that should be 
repeated is not the school year, but the education.

Based on the learning curve Pearson, Indonesia lie in $40^{\text {th }}$ position in the education mapping from 40 countries that assessed in that assessment. The assessment was assessing the mapping of access and education quality in 2013 and 2014. Based on Program for International Student Assessment (PISA) who assessed the ability of 15-year-old students in the fields of language, mathematics, and science, Indonesia ranked 39th out of 41 countries in 2000 and 69 th out of 76 countries in 2015. According to PISA, less than one percent of Indonesian students are able to use knowledge to be applied in everyday life. The cognitive abilities of Indonesian students are very low to treat problems, even using logic skills to analyze and solve problems. (Republika, 2016)

In 2016, Vice President Jusuf Kalla had declined an idea of moratorium the National Exams that delivered by previous Minister of Education and culture Muhadjir Effendy. The moratorium was proposed to continue an effort to fulfil the standard of education service, teacher quality, and school infrastructure.

At that time, government viewed that National Exam is still needed to be conducted in order to evaluate the quality of high school graduate and quality of education nationally also ensuring the persistent of student in achieving the target of high school graduate. The moratorium was declined because at that time, there is still no alternative ways in assessing those quality except the National Exams itself. (Republika, 2016)

In 2017, National Exams using Computer based system conducted simultaneously in Indonesia. However, the education quality and infrastructure were not equally in every single region. At that time some school who hasn't complete infrastructure for doing the National Exams have to registered their selves and the student has to do the national exams in the other school who have fulfil the requirements to conduct the national exams. This issue become one of barrier and prove that the mapping of the inequal distribution of education system and infrastructure in Indonesia.

According to Mardapi, the indicator of quality of education is the competence of the graduated students the competence could be including of the fulfilment of the knowledge, skills and behavioral act that showed by the graduated students. (Mardapi, 2011)

Three aspects that need to be measured in order to enhance the standard of the school. The elements are input, school and output (out or graduate) for setting. Assessment learning outcomes, related to learning experiences, are a very significant component in the educational process. All of the mechanism at formal educational institutions on will eventually lead to effects of learning that are expressed in quantitative score type. Learning results for the students are not always easy to judge. Learning goals, as is understood, span the cognitive, affective, and psychomotor domains. The field of knowledge and attitude, though observable, is fairly difficult to observe. (Idrus, 2012)

In 2019, there was discourse by Minister of Education, Nadiem Makarim that the National Exams will be abolished, the idea was because the National Exams are containing a solid and complicated materials. The abolishing was considered after doing some kind of survey and discussion with parents, student, teacher, and head principal of schools. It was assessed that National Exams only teaches about the materials, memorize the material, not the lesson competences.

Not to mention, The National Exams is not the determined the graduation of the high school students. High school students have to pass the School Exam (Ujian Sekolah) that have higher percentage in determining the graduate decision of students that might be 
different in each school because of the inequality of distribution in education system in Indonesia. The national exams also held a small percentage but not become the main determining factors for graduating sudents since 2013.

The discourse about abolishing the National Exams led the author to the research questions for this journal, which is "how was the National Exams being ineffective to be conducted". In this journal, the author would like to discuss about the uses of National Exams as the measurement for high school graduate, and what factors that shows the ineffectiveness of conducting National Exams in Indonesia. This journal also will discuss the issue in the perspective of Education theory and also using Psychological perspective in seeing the issue.

\section{LITERATURE REVIEW}

\section{High school graduate measurement}

Education activities are actually managerial activity, because it has to have planning, programming, organizing, actuating, controlling, and evaluating. In the case of graduation, students have to pass the requirements that given by school and state requirements. In terms of evaluating, the quality of education become an indicator of the graduate student, which measure the skill and knowledge that graduated students have. (Mardapi, 2011)

The competence requirements of graduation could be the ability that shown by achieving and fulfill the requirements of knowledge, skill, ad behavioral act by the graduated students. The effort on reforming the education quality could be using the way of increasing the quality of teaching and evaluating activities. By trying that way, hopefully the attempt of reforming the education quality will include the effort on perfecting the evaluation system that used to evaluate the students. (Ghofur, 2004)
Government makes the national examination a criterion for graduation from school at each stage of education, provided that the national examination only assesses cognitive abilities. Potency a student cannot be seen only from one dimension is in terms of cognitive, without recognizing that there is also an affective and psychomotor capacity in the students. (Nursyam, 2017)

National Exams

National Exams became the measurement for graduation since 2005, the measurement for high school graduation by became the one that could evaluate the understanding about concept of material and lesson subject by the students. But rather than becoming a measure in assessing the graduate students, some people look a benefit from the Ujian National. Some people fraud and seek for a gain in terms of money. For example, people who sell the answer of the Ujian Nasional to students. (Nursyam, 2017)

The results of the national examination should be used as a guide by local government in the preparation of maps for education in the area, especially in relation to teacher competence. The distribution of teacher power is therefore not based solely on a count of quantities but also on the efficiency dimension. Public graduation monitoring does not seem to be the best way to do educational mapping, because it does not identify detailed learners with academic abilities.

Graduation criteria for exams focused solely on students ' interest in solving theoretical and practical problems at national level, which means that the competency requirement applies only to cognitive aspects. Graduation benchmarks are often used to it by the national to allow the students to escape from dead grades. This situation means that the organizer and the education of the bureaucracy are not fair in giving student evaluation (exams) until they try to get around the interest of the UN. (Silverius, 2010) 


\section{THORITICAL FRAMEWORK Education}

The True meaning of education is not limited to the bookish knowledge. Education is inculcated moral values, positive thinking, attitude that suitable to survive and growth in society (Muskan, 2017). The education theory refers to theories that describe the learning and educational method, perception, and intent. The philosophy of education is sometimes called the philosophy of pedagogy, of teaching and of learning. Such theoretical frameworks investigate how we learn best so that those who teach can apply the resulting results of study to practical practice.

Modern educational research can be traced back to theoreticians like Ivan Pavlov, Hermann Ebbinghaus and Edward L. Thorndike. Pavlov's contribution to modern philosophy of learning is his "classical conditioning" concept. But the core education theories are built from learning theories that include theory of behaviorism, cognitivism, and constructivism.

Behaviorism based on the idea of independency of knowledge and the way the learner extract and could change the behavior because of the learner stimulated by the knowledge that the learner got. It also reactive with the fact of the unreceived knowledge could be a stimulant of the different behavior. Behaviorism have specific repeated actions, verbal reinforcement and insentives. It is a base for rule establishment (Pavlov, 1897).

Cognitivism is focused on the idea of processing information that received. This learning theory show the way learner or student give response from thinking and processing the information. Cognitive triggered student to reconnect and reorganize an information by finding a new concept of explanations or adapt and reuse the old one (Kohler, 1920).

Constructivism is a base in constructed learning by the experience or prior knowledge that have been had before. The way constructivism can be seen is by looking to the way student solve a problem, doing a research or doing group activities.

Author use this kind of education theory, because later, author wants to analyze the terms of education that related with evaluation making the National Exams became a measurement to measure the quality and fulfilled qualification of student.

\section{Evaluation}

The definition of Evaluation by Norman E. Gronlund (1985.p.5) mentioned as "Evaluation is a systematic process of determining the extent to which instructional objectives are achieved by pupils". That statement means that evaluation is a systematic process that determine the decision to see whether the learning objectives has been fulfil or not. In the other side, Wrightstone (1956.p.16) saw that "Educational evaluation is the estimation of the growth and progress of pupils toward objectives or values in the curriculum." Which means that Wrightstone views the evaluation as the way to look the growth and progress by the student. (Idrus, 2010)

Both of the theorists have different perspective in viewing evaluation. But when the perspective collided to be one, evaluation can be seen as a process to assess the growth and progress of student in mastering the ability that should be mastered based on objectives of learning that led to fulfilled the graduation requirements.

Learning result assessment practices are one of the attributes of the qualified educators. A competent instructor also needs input on the learning process they are going through. This was done taking into account an indicator One of the teaching success is determined by the degree of progress attained by the subject of learning.

Registered educators may want knowledge about the difficulty level of the content that they teach, as well as the approach or technique used in the learning process. By itself, one of the best ways to find out and 
acquire the knowledge that he needs, the instructor will then carry out assessment activities

Author try to use this evaluation perspective in order to analyze the way Ujian Nasional become the measurement of graduations, which means that the result of Ujian National become the evaluation of fulfilling the graduation requirements.

\section{RESEARCH METHODOLOGY}

The research started by questioning the issue after reading news about the issue of National Exams. Author started to work on forming the research question that suitable for this Journal. In this research, the author would like to use qualitative method in addressing the research question. In the author's perspective, the research methodology is including on the way of the data obtained based on logical and rational reason that provided in choosing the qualitative method, and not limited only on which method is likely to be chosen by the author. Hence, the author believes that analyzing and interpreting the data can be simpler by using qualitative method in conducting this research. Then, the result is constructed to be narrative and more descriptive in answering the research question.

After questioning the research question, Author tried to find the data available that discuss about the national exams in Indonesia, the data are journals, news, report, government publications and the claim by experts in education. The scope of limitation in this research is the national exam as an evaluation and measurement become ineffective to be conduct, hence the author would like to focus on the data that related to the topic for have a narrow down perspective which focus in the ineffectiveness of National exam.

Then, author do the data integration, means author tried to examine the suitable and corelated data that can be used as a whole data that connected to each other.
After find the suitable data that corelated each other as the result from the data integration, author analyze the data. The analysis is using qualitative method, which analyze the secondary data. In analyzing the data, author try to connect the data taken by using the theory of education and evaluation as mentioned in previous chapter.

After analyzing the data, author would interpret the data to be a complex explanation that based on analysis. For the last step, the author will try to conclude and answer the research question that mentioned in introduction by elaborating all the step that taken before.

\section{ANALYSIS}

Indonesian Government has realized the importance of education for the National and state sustainability education makes the government (state) obliged to coordinate educational porses with the best possible outcomes for its people. This is stated in UUSPN Article 11 (1) of the Government and local governments shall provide services and facilities, as well as guarantee quality education without discrimination for every citizen. It can be seen by the details of the UUSPN Article 11 (1) that stated: "Pendidikan adalah usaha sadar dan terencana untuk mewujudkan suasana belajar dan proses pembelajaran agar peserta didik secara aktif mengembangkan potensi dirinya untuk memiliki kekuatan spiritual keagamaan, pengendalian diri, kepribadian, kecerdasan, akhlak mulia, serta keterampilan yang diperlukan dirinya, masyarakat, bangsa dan negara. Pada Bab II Pasal 3, kembali ditegaskan bahwa pendidikan nasional berfungsi mengembangkan kemampuan dan membentuk watak serta peradaban bangsa yang bermartabat dalam rangka mencerdaskan kehidupan bangsa, bertujuan untuk berkembangnya potensi peserta didik agar menjadi manusia yang beriman dan bertakwa kepada Tuhan Yang Maha Esa, berakhlak mulia, sehat, berilmu, 
cakap, kreatif, mandiri, dan menjadi warga negara yang demokratis serta bertanggung jawab." But this responsibility turned up to be irony because of some fraud, unfairness, and ineffectiveness in assessing the High school graduation.

Secretary of the Research and Development Agency, Ministry of Education and Culture (Kemendikbud), Dadang Sudiyarto said the budget for the National Examination (UN) in 2019 was far lower than before. "The budget for the national exam is Rp. 210 Billion from what was Rp. 500 Billion. He explained, in addition to being borne by BOS supervisors' costs, the UN budget declined because participants in the Computer-Based National Examination (UNBK) increased rapidly. In 2019, the number of UNBK participants was 91 percent of the total national exam participants or 7,50,116 students. While last year there were only $6,287,900$ students. This results in decreased printing costs. Even though the National Exams using the computer-based technology. The aim is still not accurate. Because the material that examined are all the same standard of quality, while the standard of each school in Indonesia is still not same. It can be seen by the different quality of Schools in the city of Java and some schools in the suburban places in the same region. The way the teacher teach and the school infrastructure are still uneven. Some schools may still have no access to the computer in enough amount as the amount of student. There are also uneven accreditation of school that may affecting the conduct of the national exams with computerbased of technology.

The other reasons are it seems like the teacher is become "useless" in teaching, because the decision of student graduation was decided by the government. It also because the minister view that there is unfairness in the education system, again, because each school have a different qualification so the evaluation given was followed the quality of the schools.
There are three assessment types used to assess the graduation of students from a particular educational unit, i.e. tests for five different subject groups and school examinations and national examinations. This is as it turns out in Peraturan Pemerintah (PP) No. 19 tahun 2005 article 72 point (1) that stated "Peserta didik dinyatakan lulus dari satuan pendidikan pada pendidikan dasar dan menengah setelah: (a) menyelesaikan seluruh program pembelajaran; (b) memperoleh nilai minimal baik pada penilaian akhir untuk seluruh mata pelajaran kelompok mata pelajaran agama dan akhlak mulia, kelompok mata pelajaran kewarganegaraan dan kepribadian, kelompok mata pelajaran estetika, dan kelompok mata pelajaran jasmani, olah raga, dan kesehatan; (c) lulus ujian sekolah/madrasah untuk kelompok mata pelajaran ilmu pengetahuan dan teknologi; dan (d) lulus Ujian Nasional." Passing the National Exams becoming one last point in the article, and this can be changed if the government pay more attention to the recent conditions that the National exams only become the last ticket for graduating high school and it is stop in that point.

This is ineffective, as the author view that the previous model of National Exams, which is EBTANAS, can be used too examine the students whether they could enter the public university, or have to enter the private university. In this time, The examination for going to the public university has other way which usually known as SNMPTN (Seleksi Nasional Masuk Perguruan Tinggi Negeri) and SBMPTN (Seleksi Bersama Masuk Perguruan Tinggi). Where the SNMPTN are assessed the student based on the score of the students report card and student achievement, while for SBMPTN assessed the student by conducting tests such as other examination.

This, viewed by author as a waste. The waste is for the money, time, and becoming a longer bureaucracy that giving possibilities on another unfairness and act of fraud by other 
authorities that handled the examination for entering the university. Its different from the old times, where EBTANAS becoming the assessing measurement not only for the high school graduation, but also to enter the university. Passing the EBTANAS were prestigious and the aim of EBTANAS is efficient. This become one of the reason on the recent National Exams are not effective to be conduct.

Conny Semiawan and Winarno Surakhmad, two educational experts from the Ikatan Sarjana Pendidikan Indonesia (ISPI), shared their views on the National Examination. Conny recalled that evaluating the quality of education and determining students' learning outcomes are two distinct issues. They may draw some inference from learning outcomes relevant to educational efficiency, but not directly, and this involves other elements, such as facilities and inputs that need to be tailored to learning demands. But Winarno sees this from a different perspective. According to him, so far exams such as this UN are the product of our ignorance, especially politicians who do not want to see the educational considerations inside educating the country. Winarno added in his comment that a single disease that used to be a UN denominada in Indonesia now was not a sentimental illness. That is, if the UN is refused, republic, but if the efforts to bring the nation down are ignored, then that country must die. This viewed by the author that the statement by the both Conny and Winarno has a same perspective that by initiating quality enhancement through the UN, Indonesia education system is definitely on the wrong track.

Next, discussing about the system of grading the National Exams itself, The Minister of Education and Culture, Mr. Makarim view that National Exams not supposed to be the suggestion to controlled the education quality. Education quality cannot be based on the number of students that received excellent score in National Exams. Because there were also clever but cannot pass the National Exams. The other is, National Exams doesn't build a hardworking character, instead it built cunning character because the National Exams was forceful.

This one can be seen of there's an example of action of fraudulence, where Inspector General of the Ministry of Education and Culture, Muchlis R Luddin said that during the implementation of the 2019 National Examination at SMA / SMK / MA level there were 202 reports of fraud. Yet the number had shrunk to 126 cases, after being confirmed. With the details can be seen that the acton of fraud are increasing as the Inspector general mentioned that in 2017, there were 71 participants suggested cheating, in 2018 just 79 participants, and in 2019 the most were 126 confirmed. (Abdi, 2019).

Based on the Education theory that also include the behaviorism, the author saw this refers to the character of the student that hopefully affected by the education. For the characters of the student, the score of National exams only scored the ability of memorize the materials, character education and development becoming the last thing to be scored, This, becoming a new point to add the reason for the ineffectiveness of National Exams. The education system and the evaluation such as national exams ideally have to assess the character of the student, as the student is the next generation that will build the nation in the future. The author view that based on the forceful situation that student have to pass the national exams, and the action of fraud has emerge, this reflecting the characteristic of student that cannot be a good things to say.

\section{CONCLUSION}

In the end of this research, author would like to answer the research question of how the national exam is ineffective to be conduct based on the analysis.

National exams are ineffective to be conducted as the aim of conducting national 
exams is only for assessing the ability of student to memorize the materials, not to implement the knowledge that they got, and no further assessment for the characteristic of the student. National exams become ineffective also because the exams is only have little percentage for the student tu be graduated, while the most of the percentage that measure the graduations is on the school examination.

If the government did not want to abolish the national exams, there are things to be considered to enhance the effectiveness in conducting the national exams, which to considered the national exams to be not only or the graduation for the high school students, but also to become examination for entering public university just like EBTANAS in the previous era. Security and quality of invigilator are also have to be considered, this to ensure that there will be no actions of fraud in conducting the national exams in the future.

\section{REFERENCES}

Abdi, alfian P. (2019). Kemendikbud Klaim Anggaran UN 2019 Turun Jadi Rp210 Miliar.Jakarta. Retrieved from tirto.id: https://tirto.id/kemendikbud-klaimanggaran-un-2019-turun-jadi-rp210$\underline{\text { miliar-dj2b }}$

Ghofur. (2004). Pedoman Umum Pengembangan Penilaian. Jakarta: Depdiknas

Idrus, M. (2010). Ujian Nasional Dalam Konsep Pendidikan. Millah, 202-218.

Mardapi.(2011). PENGEMBANGAN INSTRUMEN PENGUKUR HASIL BELAJAR NIRBIAS DAN TERSKALA BAKU.Jurnal penelitian dan Evaluasi Pendidikan, 2, 326-341

Media Indonesia.(n.d.). Alasan Ujian Nasional Dihapus. Jakarta. Retrieved from https://mediaindonesia.com/read/detail /277115-ini-sejarah-ujian-nasional-diindonesia

Nursyam. (2017). Efektifitas Pelaksanaan Ujian Nasional Tingkat Sekolah Menengah
Atas Negeri Oleh Dinas Pendidikan dan Pengajaran Kota Palu Provinsi Sulawesi Tengah. Jurnal Katalogis, 5, 11-21.

Republika. (2016, December 10). UN dan Mutu Pendidikan . Retrieved from Republika.co.id: https://republika.co.id/berita/ohygo220 /un-dan-mutu-pendidikan

Silverius, S. (2010). Kontroversi Ujian Nasional Sepanjang Masa. Jurnal Pendidikan Dan Kebudayaan, 16, 195-205. 